\title{
Determinants of Bond Rating and its Implications to Corporate Bond Yield
}

\author{
Aceng Abdul Hamid, Arifin Siagian, A. Razak, Endri Endri
}

\begin{abstract}
Identifying the factors that affect bond ratings is important in relation to investment decisions in long-term debt securities because they have an impact on corporate bonds. The research objective is to analyze the factors that influence bond ratings and their implications for corporate bond yields, both partially and simultaneously. This study uses a logistic regression model to estimate the determinants of corporate bond ratings and a panel data regression model to estimate the implications for corporate bond yields, by taking samples of corporate bonds listed on the Indonesia Stock Exchange (IDX) during the 2012-2016 period with a number of samples research with as many as 36 corporate bonds. Based on the results of the study, using the logistic regression method, the following research findings were obtained: company size, liquidity, leverage and profitability simultaneously affected bond ratings with a contribution of $33.62 \%\left(R^{2}\right)$. In addition, the size and liquidity of the company have a positive and significant effect on bond ratings. While the results of the panel data regression analysis, it was found that company size, liquidity, leverage, profitability and bond rating simultaneously affected bond yields with a contribution of $70.4 \%$ (R2) while $29.6 \%$ was influenced by other variables. In addition, the size and leverage of the company has a negative and significant effect on the yield of corporate bonds. This study also shows that the larger the size of the company, the less sensitive the changes in bond yields and vice versa, the smaller the size of the company, the more sensitive it is to changes in corporate bond yields.
\end{abstract}

Keywords : bond rating, corporate bond yield, logistic regression, panel data regression

\section{INTRODUCTION}

Stock is a claim of ownership in a company, while a bond states a creditor's claim in a company. Based on statistical data on the Indonesian Capital Market processed by the Financial Services Authority (OJK), an increase in trade in corporate bonds in Indonesia is shown in Table 1.

Table 1.Trading of Corporate Bonds in Indonesia (in Trillions of Rupiah)

\begin{tabular}{|l|l|c|}
\hline \multirow{2}{*}{ Year } & \multicolumn{2}{|c|}{ Outstanding } \\
\cline { 2 - 3 } & Nominal & Change \\
\hline
\end{tabular}

Revised Manuscript Received on December 30, 2019.

* Correspondence Author

Aceng Abdul Hamid*, Universitas Pamulang, Tangerang Selatan, Indonesia;

Arifin Siagian, Universitas Satya Negara Indonesia, Jakarta, Indonesia; A. Razak, Politeknik Negeri Pontianak, Pontianak, Kalimantan Barat, Indonesia;

Endri Endri*, Universitas Mercu Buana, Jakarta, Indonesia;

(C) The Authors. Published by Blue Eyes Intelligence Engineering and Sciences Publication (BEIESP). This is an open access article under the CC BY-NC-ND license (http://creativecommons.org/licenses/by-nc-nd/4.0/)

\begin{tabular}{|c|c|c|c|} 
& $\mathbf{( R p )}$ & $\mathbf{( R p )}$ & $\mathbf{( \% )}$ \\
\hline 2007 & 84,55 & 0 & 0 \\
\hline 2008 & 72,98 & $-11,57$ & $-13,68 \%$ \\
\hline 2009 & 88,33 & 15,35 & $21,03 \%$ \\
\hline 2010 & 115,35 & 27,02 & $30,59 \%$ \\
\hline 2011 & 146,97 & 31,62 & $27,41 \%$ \\
\hline 2012 & 187,46 & 40,49 & $27,55 \%$ \\
\hline 2013 & 218,22 & 30,76 & $16,41 \%$ \\
\hline 2014 & 223,46 & 5,24 & $2,40 \%$ \\
\hline 2015 & 249,88 & 26,42 & $11,82 \%$ \\
\hline Average & $\mathbf{1 2 8 , 3 7}$ & $\mathbf{2 2 , 0 3}$ & $\mathbf{1 8 , 0 3 \%}$ \\
\hline
\end{tabular}

Outstanding corporate bonds in accordance with Table 1 . generally show an increase in trade with an average increase of $18.03 \%$ from 2007 to 2013. In contrast to bond issuances which only showed an increase from 2007-2011 which then declined from 2012-2013. Seen in the table, corporate bond issuance shows an average increase of $35.48 \%$ with the highest emissions occurring in 2011 of 65.66 trillion rupiah. The existence of this phenomenon shows that actually corporate bonds began to bloom traded in Indonesia.

The phenomenon in Indonesia occurs to some issuers who experience defaults (default) which happen to have investment-grade ratings. In 2009, default risk occurred in companies that were quite popular with the public. PT. Mobile-8 Telecom Tbk. which issued Bond I Year 2007, has failed to pay twice for the coupons of March 15, 2009 and June 15, 2009 with bonds worth Rp 675 Billion due in March 2012. As of June 2008 and 2009, PT. Mobile-8 Telecom Tbk The Indonesia Bond Market Directory is idBBB +. As of June 2010, the ranking was downgraded to idD. In addition to the Rupiah, the issuer's subsidiary, Mobile-8 Telecom Finance Company BV, was also declared defaulted by the bond trustee, the Dollar issued in August 2007 and due in March 2013 worth US \$ 100 million, DB Trustees, dated December 16, 2008 due to violations bond clause regarding the transfer of shares of PT. Global Mediacom Tbk. to Jerash Investment in September 2008 from 59\% to 19\%.

According to Adam et al. (2003), one of the reasons why rating bonds issued by rating agencies could be because rating agencies do not monitor the company's performance every day. Rating agencies can only assess after the occurrence of an event that causes a ranking change that causes market participants to pay more attention to the information the company has directly as the basis for bond investment decisions. 
Financial statement analysis in the form of financial ratio analysis and statistical calculations can be used to detect under or overvalued a security (Kaplan \& Urwitz, 1979). Research on financial ratios in Indonesia is mostly related to stock prices or company performance. A number of studies examining bond ratings in Indonesia are relatively rare. This is due to the limited data on bonds and investors' knowledge of bonds. Wansley et al. (1992) also stated that the majority of bond trading is conducted through the negotiating market (over the counter market) and historically there is no price information available at the time of issue or at the time of sale.

\section{LITERATURE REVIEW}

\subsection{Agency Teory}

Jensen and Meckling (1976) define agency relationship as a contract between the manager (agent) and the owner (principal) of the company. One or more principal gives the authority and authority to the agent to carry out the interests of the principals. Managers as parties who are given authority over company activities and are obliged to provide financial reports are likely to report something that maximizes their utility and this triggers agency conflicts

\subsection{Signaling Theory}

Signal theory or signaling theory put forward by Ross (1977), which states that company management has better information and needs to convey it to investors so that the value of the company's shares increases. The fact that management does have better information from investors about the value of the company and the prospects of the company in the future, has exposed investors to high uncertainty about their investments. The information asymmetry encourages managers to convey their information in the hope that the information will be responded to by investors as a signal of certain events that can affect the value of the company. Thus signaling theory explains that managers try to give signals with the aim of reducing information asymmetry.

\subsection{Yield to maturity}

Yield to maturity (YTM) is the internal rate of return IRR obtained from a bond if the bond is held until the due date. YTM is a bond return which equates the purchase price with cash flow (coupon and principal). YTM can be used to compare one bond to another. Investors will choose bonds that provide a high YTM at the same level of risk and maturity (Ahmad, 2009). Yield to maturity (YTM) can be interpreted as a compound rate of return that investors will receive if they buy bonds at the current market price and hold the bonds until maturity. Yield to maturity of a bond is the rate of return (yield) obtained by an investor when holding a bond until maturity. YTM evaluates both interest income, capital gains and cash flow received throughout the life of the bond market until maturity date (Sihombing, 2014).

\subsection{Bond Rating}

Bonds that are sold to the public in the perspective of the buyer see it according to the rating. The rating reflects the credibility and prospect of the bonds being purchased to be one of the company's current assets. Therefore, not just any bond will be bought but the bond purchased is mainly based on recommendations from rating agencies which have been trusted for evaluation at the international level (Afonso, 2003)). The bond rating process is carried out by a rating agency. Rating agencies in Indonesia are PT. Pefindo (Indonesian Rating Agency). The rating given by the rating agency will state whether the bonds are at investment grade or non-investment grade. Investment grade is a high grade bond that reflects low credit risk (high creditworthiness). Non-investment grade is a low grade bond(low grade) that reflects high credit risk (low creditworthiness).

\subsection{Size of Bond Rating}

Company size is one of the accounting variables that affect bond ratings. According to Miswanto and Husnan (1999) company size can be measured using total assets, sales or equity. Meanwhile, according to Elton and Gruber (1995) large companies are less risky than small companies because small companies have a greater risk. If the larger the company, the potential to diversify non-systematic risk is also greater so that the risk of the company's bonds decreases.

\subsection{Liquidity towards Bond Rating}

A company that is able to meet its financial obligations on time means that the company is in a liquid state and has a current asset greater than its current debt. Adam et al. (2003) states that a high level of liquidity will indicate the strength of the company's financial condition so that it will financially affect the prediction of bond ratings. Adam et al. (2003) states that a high level of liquidity will indicate the strong financial condition of the company so that financially will affect the prediction of bond ratings.

\subsection{Leverage on Bond Rating}

The leverage ratio measures how much a company is financed with debt (Chen, 2007). If this ratio is high enough, then it shows the high use of debt, so this can make a company experiencing financial difficulties, and usually has a substantial bankruptcy risk. The greater the company's leverage ratio, the greater the risk of company failure. The lower the leverage of a company, the better the rating given to the company (Adam et al. 2003). This indicates that companies with high levels of leverage tend to have low ability to fulfill their obligations.

\subsection{Profitability to Bond Ratings}

Investment in the form of bonds is actually not directly affected by the profitability of the company, because no matter how much profit is able to be generated by the company, the bondholders still receive a fixed interest rate. However, analysts remain interested in the company's profitability because profitability is perhaps the single best indicator of the financial health of the company (Sari \& Endri, 2019). If the company's profit is high, it will give an upward ranking too so that this variable is said to affect the bond rating prediction.

\subsection{Size of bond yields}

The size of the company can be measured using total assets, sales, or capital. One benchmark that shows the size of the company is the size of the assets of the company.

Blue Eyes Intelligence Engineering 
Companies that have a large total assets show that the company has reached the maturity stage in which at this stage the company's cash flow is positive and is considered to have good prospects in a relatively long period of time, while also reflecting that the company is relatively more stable and more able to generate profits compared to companies with small total assets (Bessembinder, 2002). Bhojraj \& Sengupta (2003) states that the larger the company will have a higher bond rating because of low market risk that will reduce yield.

\subsection{Liquidity of Bond Yields}

Bessembinder (2002) states that liquidity is a problem related to the problem of a company's ability to meet obligations that must be met immediately. Burton et al. (2000) states that a high level of liquidity shows the company's financial condition in good condition.

\subsection{Leverage on Bond Yield}

Companies that have a greater proportion of debt in their capital structure will have greater agency costs. Companies that have high leverage have more obligations to meet the long-term information needs of creditors (Wallace et al, 1994). The leverage ratio that is too high indicates excessive debt, and indicates the possibility that the company will not be able to create sufficient profits to pay its obligation obligations (Endri et al, 2019).

\subsection{Profitability to Bond Yields}

Profit can be used as a measure to assess the company's prospects. Profit can be used to: (a) evaluate management performance, (b) estimate earnings power, (c) predict future earnings or (d) assess investment risk, or loan to the company (Harahap, 2018). The higher the profit, the more likely it will be to attract investors to invest their funds in the hope of obtaining greater returns. In an investment also tends to occur agency conflict between managers and investors. Managers tend to take advantage of the company's profitability to maximize the company's utility. Conversely, investors or creditors tend to want high returns from the profits obtained.

\subsection{Rating of Bonds to Bond Yields}

Kim \& Gu (2004) stated that bonds rated investment have a superpremium price and have a low yield. Bonds with a relatively higher risk of default (lower rating) will offer a higher yield compared to bonds with relatively lower risk (higher rating). Bond and yield ratings are inversely proportional, if bond ratings increase, yields will go down and vice versa, if bond ratings go down, yields will increase (Jewel \& Livingston, 2000).

\subsection{Hypothesis}

Based on the assumptions stated in the formulation of the problem and frame of mind above, the hypothesis in this study is as follows:

$\mathrm{H} 1$ :Size level has a positive effect on

Bond Rating

H2:Liquidity level has a positive effect on bond ratings

H3:The level of leverage has a negative effect on bond ratings

H4:The level of profitability has a positive effect on bond ratings

H5:Size, Liquidity, Leverage and Profitability levels together affect the bond rating
H6:Size level has a negative effect on bond yields

H7:Liquidity level has a negative effect on bond yields H8:The leverage rate has a positive effect on bond yields H9:The level of profitability has a positive effect on bond yields

H10:The Bond Rating Level has a negative effect on the Bond Yield

H11:The level of size, liquidity, leverage, profitability and rating of bonds together affect the bond yield

\section{RESEARCH METHODOLOGY}

This study uses quantitative research methods that emphasize testing theories through measurement of research variables in the form of numbers and conducting analysis with statistical procedures. This study was conducted to find out how the determinants of financial factors for bond ratings and their implications for Yield To Maturity. The object of research is companies listed on the Indonesia Stock Exchange (IDX) that publish financial statements for 2012-2016.

This study uses a Cross Sectional and Time Series approach. The data examined and processed are secondary data on companies that issue bonds on the Indonesia Stock Exchange for 5 years, from 2012 to 2016. The data analysis method is also used to test the hypotheses formulated in the previous chapter, the model used in This research is a panel data regression model (a combination of time series and cross section) and logistic regression using the help of the computer statistics application program EViews 9.0.

\section{RESULTS AND DISCUSSION}

\begin{tabular}{|c|c|c|c|c|}
\hline & \multicolumn{4}{|c|}{ Table 2. Wald Test } \\
\hline & Coefficie & & & \\
\hline & nt & Std. Error & z-Statistic & Prob. \\
\hline C & -3.925246 & & & \\
\hline SIZE & 756 & 0.0461 & & 0.0261 \\
\hline LIQ & & & 4.728923 & 0.0000 \\
\hline DER & 0.026536 & 0.060039 & 0.441971 & 0.6585 \\
\hline ROA & -0.001783 & 0.006004 & -0.296949 & 0.7665 \\
\hline
\end{tabular}

Based on the calculation above shows that company size and liquidity have a positive and significant effect on bond ratings. The binary logistic regression equation models as follows:

Probability $=$ exp-3.925246 +0.102756 SIZE +2.984026 $\mathrm{LIQ}+0.026536 \mathrm{DER}+-0.001783 \mathrm{ROA}) / 1+\operatorname{ext}(-3.925246$ +0.102756 SIZE + 2.984026 LIQ + 0.026536 DER + -0.001783 ROA)

Table 3. Pseudo R Square

Pseudo R-squareds

\begin{tabular}{ll}
\hline \hline Efron & 0.252201 \\
McFadden & 0.234139 \\
Adjusted Mcfadden & 0.181699 \\
Cox-Snell & 0.219679 \\
Nagelkerke & 0.336240 \\
\hline \hline
\end{tabular}


Nagelkerke R Square value of 0.336240 and Cox \& Snell R Square 0.219679 , while according to McFadden's calculation of 0.234139 , which shows that the ability of independent variables in explaining the dependent variable is according to nagelkerke by 0.336240 or $33.62 \%$ and there are $100 \%$ $33.62 \%=62.38 \%$ other factors outside the model that explain the dependent variable.

\section{Table 4. Fixed Effect Panel Data Model Estimation}

Dependent Variable: YTM

Method: Panel Least Squares

Sample: 20122016

Periods included: 5

Cross-sections included: 36

Total panel (balanced) observations:

180

\begin{tabular}{|c|c|c|}
\hline \multirow[b]{2}{*}{ Variable } & Coeffici & t-Statisti \\
\hline & ent Std. Error $\quad$ c & Prob. \\
\hline \multicolumn{3}{|c|}{1.16027} \\
\hline \multirow[t]{2}{*}{$\mathrm{C}$} & $\begin{array}{lll}0 & 0.10667010 .87722\end{array}$ & 0.0000 \\
\hline & $\begin{array}{ll}-0.0486 & -8.90314\end{array}$ & \\
\hline \multirow[t]{2}{*}{ SIZE } & $\begin{array}{lll}45 & 0.005464 & 6\end{array}$ & 0.0000 \\
\hline & $\begin{array}{ll}-0.0041 & -0.44802\end{array}$ & \\
\hline \multirow[t]{2}{*}{ LIQ } & $\begin{array}{lll}99 & 0.009372 & 6\end{array}$ & 0.6548 \\
\hline & $\begin{array}{ll}-0.0040 & -2.95251\end{array}$ & \\
\hline \multirow[t]{2}{*}{ DER } & $\begin{array}{lll}54 & 0.001373 & 0\end{array}$ & 0.0037 \\
\hline & $\begin{array}{ll}-8.62 E- & -0.88907\end{array}$ & \\
\hline \multirow[t]{2}{*}{ ROA } & 05 9.70E-05 5 & 0.3755 \\
\hline & $\begin{array}{ll}-0.0019 & -1.03427\end{array}$ & \\
\hline \multirow[t]{2}{*}{ GRADE } & $\begin{array}{lll}37 & 0.001873 & 6\end{array}$ & 0.3028 \\
\hline & $\begin{array}{c}\text { Effects } \\
\text { Specification }\end{array}$ & \\
\hline
\end{tabular}

Cross-section fixed (dummy variables)

R-square 0.70400 Mean dependent

d 8var 0.118683

Adjusted

R-square 0.61883 S.D. dependent

d Ovar

0.067676

S.E. of

regressio 0.04178 Akaike info

n 3criterion

Sum

$-3.315595$

squared $\quad 0.24266$

resid 6 Schwarz criterion

Log

$-2.588311$

likelihoo 339.403 Hannan-Quinn

d 6criter.

F-statisti 8.26516 Durbin-Watson

C 3stat

1.141254

Prob(F-st 0.00000

atisti)

0

Source: Data processed

Estimation results from the use of the fixed effect model for the panel data regression method can show the 36th constant of corporate bonds listed on the Indonesian stock exchange which were selected samples in this study, although with the same regression coefficient for each bond variable that affects the yield corporate bonds. The results above show that company size and liquidity have a negative and significant relationship to bond yields.

\subsection{Company Size (SIZE) to Bond Rating (GRADE).}

Empirical findings of the results of this study indicate that the Wald p value of $0,0009<0.05$ so that receiving $\mathrm{H} 1$ or which means Size has a significant effect on the Bond Rating. Companies with large size scale are easier to access to the capital market while companies with small size will find it more difficult to access to the capital market. The size of the company also determines the bargaining power (shaking power) in financial contracts. Large companies can choose funding from various forms of debt including special offers that are more profitable than those offered by small companies.

Therefore different company sizes will affect the sensitivity of the relationship between bond ratings and non-systemic risk (default risk). The greater the size of the company, the potential to diversify non-systematic risk is also greater so that the risk of the company's bonds decreases and increases bond ratings.

\subsection{Liquidity (LIQ) of Bond Rating (GRADE).}

Empirical findings of the results of this study indicate that the value of the Wald p value of $0.0000<0.05$ so that receiving $\mathrm{H} 1$ or which means liquidity has a significant positive effect on bond ratings. High liquidity shows the company's strong financial position that will affect bond ratings. These conditions will facilitate companies to attract investors to invest in their companies (Amalia, 2013). The results of the study are in line with empirical research by Carson and Scott (1997) and Bouzoita and Young (1998) found a relationship between liquidity and bond ratings.

\subsection{Leverage (DER) to Bond Rating (GRADE).}

Empirical findings of the results of this study indicate that the value of the Wald p value of $0.6585>0.05$ so that it accepts $\mathrm{HO}$ or which means leverage does not have a significant partial effect on bond ratings. There are 16 of 36 corporate bonds used in this study, which are banking company bonds. Most of the funds managed by banks are funds from the public (third parties), in the accounting system, third-party funds are included in the liabilities so that it leads to the amount of debt that is greater than the amount of equity owned by the company and then the DER value becomes high.

\subsection{Profitability (ROA) of Bond Ratings}

The independent variable hypothesis is that the proposed profitability (ROA) is not accepted or said to be negative and is not significant to the dependent variable, namely bond rating. The reason that supports the results of this research is that profitability measurement based on ROA proxy is not right. This is because ROA shows the results (return) on the use of company assets. This is proven based on the results of research, Satoto (2011), Pandutama (2012),

Published By: 
Terry (2011) and this study uses profitability variables with a Return on Asset (ROA) proxy. The results state that profitability has no significant effect on bond ratings. This measurement will be suitable if applied to assess the effectiveness of management in managing investments or measuring the rate of return on investment.

\subsection{Company Size (SIZE), Liquidity (LIQ) Leverage} (DER) and Profitability (ROA) of Bond Ratings.

Based on estimation and analysis of empirical results on logistic regression data concludes that the four variables in this study, namely profitability, leverage, company size and liquidity affect bond ratings simultaneously and are able to explain bond rating variables of 0.336240 , or 33.624 percent while the remaining $62.38 \%$ (100\% $33,624 \%$ ) influenced by other variables not included in this study. p value of Chi-Square of 0.000000 is smaller than the error rate (alpha) 0.05 (which has been determined) so that all determinant variables of bond ratings together have a positive and significant effect on bond ratings.

\subsection{SIZE to YTM}

The negative coefficient sign indicates that the larger the size of the company, the lower YTM bonds will be. So if investors who are risk takers want to invest in bonds, they should invest their capital in bonds issued or sold by small-scale companies because they will offer large yields. As for investors who are risk averters, they should invest in bonds that are sold or issued by large-scale companies with lower bond yields but have a greater level of security. Therefore, investors need to consider the size of the company in the financial statements of the issuing company to be used in the decision to buy the bond.

\subsection{Liquidity towards Yield}

Liquidity has no effect on bond yields, this is indicated because the value of the majority of bond issuing companies has a high value, especially banking companies. So investors assume that a high liquidity value is normal or a condition that must be met by the company, so that data on the liquidity value when bond issuance is not responded to significantly by investors.

The results of this study also prove that signaling theory is not proven in testing the effect of variable liquidity on bond yields, high liquidity value is a good form of signal for investors because it shows the company is in a liquid condition. However, the results of the study show that investors do not respond significantly because high liquidity values are considered to be normal or are conditions that must be met by the company.

\subsection{Leverage on Returns}

The negative relationship between leverage and bond yields is likely due to issuers' concerns about the high inflation rate in the year (2012: 4.3\%, 2013: 8.36\%, 2014 8.36\% and 2015: 3.35\%) which could have an impact on yields . So that issuers try to reduce risk by reducing their leverage so that bonds issued remain attractive to investors and the risks they bear are not too high.

\subsection{Profitability towards Yield}

t-test results can be seen in table 5.22 above. Given the prob value. t count of 0.3755 (shown in Prob.) is greater than the error rate (alpha) of 0.05 (which has been determined) then it can be said to be insignificant. The independent variable hypothesis is that the proposed profitability (ROA) is not accepted or said to be negative and is not significant to the dependent variable, namely Bond Yield (YTM).

Profitability has no significant effect on bond yields. This is caused when the higher the level of profitability of the company, the cash flow to pay principal and interest bonds becomes smoother and the risk of default is lower. This gives a signal to investors that the company is in good condition and indicates that investment risk is low and investment security is more secure. The more investors feel safe in investing their capital, investors tend not to expect high bond yields.

\subsection{Rating of Bonds to Yield}

Empirical findings from this study indicate that bond ratings (GRADE) are negative and not significant to the dependent variable, namely corporate bond yields. This is because bond ratings tend not to change or remain stable for the duration of the study period. For example, for bonds which for the period 2012-2016 (5 years) can receive the same rank in a row.

\subsection{Size of the company, liquidity, leverage, profitability} and rating of bonds together (simultaneously) against corporate bond yields.

Based on the panel data regression coefficient test using the f-test (simultaneous) testing the equation for all variables in the model is done using the f-test. $\mathrm{f}$ test results as shown in table 5.21 shows the f-statistic value of 8.265163 shows positive results. with a probability value of 0.000000 less than $\alpha=0.05$ which means that the proposed hypothesis is feasible and said to be significant This means that the variable company size, liquidity, leverage, profitability and bond rating together (simultaneously) affect corporate bond yields by contributing and can be explained by corporate bond yields of 0.704008 or 70.4008 percent.

\section{CONCLUSION}

This study aims to examine the factors of company size, liquidity, leverage and profitability of bond ratings and their implications for corporate bond yields. Based on the test results show that company size, liquidity has a positive and significant effect on corporate bond ratings, while leverage and profitability have no effect. Yields are negatively affected by company size and leverage variables, while liquidity, profitability and bond ratings have no effect.

Further research can add other variables such as: Interest Rates, Maturity, Growth, Productivity, Bond Guarantees, Auditor Quality, Solvency, Coupons, Exchange Rates, Institutional Ownership, Corporate Governance and Macroeconomic Factors. This research can also be developed using a cointegration panel data regression model that considers that the mean (mean) and variance is constant over time so that the expected estimation results are better.

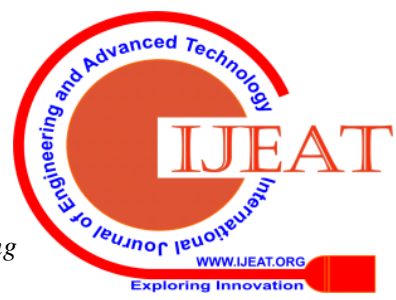




\section{REFERENCES}

1. Adams, M., Burton, B., \& Hardwick, P. (2003). The determinants of credit ratings in the United Kingdom insurance industry. Journal of Business Finance \& Accounting, 30(3/4), 539-572. doi: 10.1111/1468-5957.00007.

2. Afonso, A. (2003). Understanding the determinants of sovereign debt ratings: Evidence for the two leading agencies. Journal of Economics and Finance, 27(1), 56-74.

3. Ahmad, N., Muhammad, J. \& Masron, T. (2009). Factors Influencing Yield Spreads of the Malaysian Bonds. Asian Academy of Management Journal, 14 (2), 95-114

4. Bessembinder, H. (2002). Tick size, spreads, and liquidity: An analysis of Nasdaq Securities trading near ten dollars. Journal of Financial Intermediation, 9(3), 213-239

5. Amalia, Ninik. (2013). Pemeringkatan Obligasi Pefindo: Berdasarkan Informasi Keuangan. Accounting Analysis Journal, 2(2), 139-147.

6. Bhojraj, Sanjeev \& Sengupta, Partha. (2003). Effect of Corporate Governance on Bond Ratings and Yields: The Role of Institusional Investor and Outside Directors, The Journal of Business,76(3), 455-475

7. Bouzouita, R. \& Young, A. J. (1998). A Probit Analysis of Best Ratings. The Journal of Insurance Issues, Spring: 23-34.

8. Carson, J. M. \& Scott, W. L. (1997). Life Insurers and the "Run on the Insurer" Exposure. Journal of the American Society of CLU \& ChFC, March: 44-48.

9. Chen, L., Lesmond, D. A., \& Wei, J. (2007). Corporate Yield Spreads and Bond Liquidity. Journal of Finance, 6(1), 119-149

10.Endri, Endri., Mustafa, Bob., \& Rynandi, Oscar. (2019). Determinants of Debt Policy of Real Estate and Property Companies Listed on the Indonesia Stock Exchange, International Journal of Economics and Financial Issues, Econjournals, 9(2), 96-104. DOI: https://doi.org/10.32479/ijefi.7618

11.Harahap, I. Manggara. (2018). Impact of Bank Performance on Profitability, Scholars Journal of Economics, Business and Management (SJEBM), 5(8): 727-733.

12.Jansen, Michael \& William Meckling. (1978).Theory of the Firm Managerial Behavior, Agency Cost and Ownership Structure, Journal of Financial Economics, 3, 305-360.

13.Jewell, Jeff \& Livingston, Miles. (2000). The Impact of a Third Credit Rating on Pricing of Bond, The Journal of Fixed Income, 10 (3), 69-85

14.Sari, F. Nofita \& Endri, Endri. (2019). Determinants of Return on Assets (ROA) On Conventional Banks Listed On Indonesian Stock Exchange (IDX) Period 2013 - 2017, IOSR Journal of Business and Management (IOSR-JBM), 21 (4. Ser. II), 52-62. DOI: 10.9790/487X-2104025262

15.Satoto, S. H. (2011). Analisis Faktor-faktor yang Mempengaruhi Bond Rating. Karisma, 5, 104-115.

16.Sihombing, P., Siregar, H., Manurung, A. \& Santosa, P. (2014). Determinants of the Indonesia Government Yield Curve. International Journal of Information Technology and Business Management, 25 (1), 22-35.

17.Terry, S. D. (2011). Pengaruh Corporate Governance Terhadap Peringkat Dan Yield Obligasi Di BEI. JRMB, 6(11), 11-30.

18.Wansley, James W., John L. Glascock \& Terence M. Clauretie. (1992). Institutional Bond Pricing and Information Arrival: The Case of Bond Rating Changes. Journal of Business Finance and Accounting 19 (Sept): 733-750.

19.Wallace, R S Olusegun, Naser, Kamal \& Mora, Araceli. (1994). The Relationship Between The Comprehensiveness of Corporate Annual Reports and Firm Characteristics in Spain, Accounting \& Business Research, 25 (97), 41-53

\section{AUTHORS PROFILE}

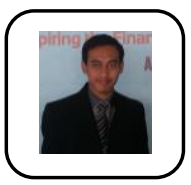

Dr. Aceng Abdul Hamid holds a Doctor of Philosophy in Management Science with a specialization in Financial Management, University of Persada Indonesia Y.A.I. Jakarta. Currently he is a lecturer in the Bachelor of Industrial Engineering program, Faculty of engineering, at Pamulang University, Tangerang Selatan - Indonesia. He has written many papers in various international journals. His research interests include engineering, econometrics, finance, decision making, investment and banking.

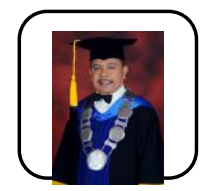

Dr. Arifin Siagian completed his Doctor of Management program at Universitas Persada Indonesia (UPI) YAI, Jakarta, Indonesia. Currently he is a senior lecturer in the Master of Management Program, Postgraduate at Universitas Satya Negara Indonesia (USNI), Jakarta. Much research has been done and published in

international journals. Research interests include corporate finance, investment, and capital markets.

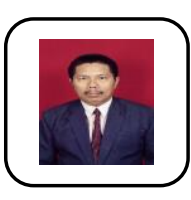

governance

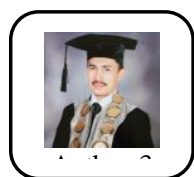
Jakarta, Indonesia. He has written many papers in various
urnals. His research interests include finance, investment, capital markets, banking and econometrics

Dr. A. Razak holds a Doctor of Accounting degree from is now the head of the Accounting study program at Politeknik Negeri Pontianak, West Kalimantan, Indonesia. Field of research expertise, including; financial accounting, capital markets and corporate

Dr. Endri holds a Doctor of Philosophy in Management Science with a specialization in Financial Management, Universitas Indonesia (UI), Depok. Currently, he is a senior lecturer in the Master of Management Program, Postgraduate at Universitas Mercu Buana (UMB), 